\title{
"For I Hate Divorce," says the Lord: Interpreting Malachi 2:16 in relation to prohibition of divorce in some churches in Nigeria
}

\author{
Solomon O. Ademiluka (University OF South Africa) \\ ABSTRACT \\ This article examined Mal 2:16 in relation to the prohibition of divorce \\ today in some churches in Nigeria. The text is perhaps the most \\ commonly quoted passage by preachers to support prohibition of \\ divorce, possibly because many of the English versions make it a direct \\ condemnation from God and preachers rarely consider other English \\ versions that read differently. It was found out that the passage relates \\ to certain Jewish men who divorced their native wives and married \\ women of foreign faiths. It was also discovered that in view of Deut 24:1- \\ 4, among other OT texts, Mal 2:16 could not have prohibited divorce. \\ Rather, what it condemns is the purpose of the divorce, namely to marry \\ women of foreign faiths. Hence, Mal 2:16 is relevant in contemporary \\ Nigeria, not as a prohibition of divorce, but in the context of marriage \\ abandonment.
}

KEYWORDS: Church; divorce; mixed marriage; Malachi; treachery.

\section{A INTRODUCTION}

The subject of divorce is an existential problem everywhere but this article studies it in the Nigerian context as it relates to Christians. Whereas many Nigerian Christians find themselves in problematic marriages from which they would want to be freed, their churches and a host of preachers declare divorce unbiblical. There are several passages quoted in support of the prohibition of divorce but perhaps the most commonly cited is Malachi 2:16, apparently because many English versions make it a direct speech from God: "For I hate divorce, says the LORD the God of Israel ..." (RSV). As Nigeria is a vast country, the study of a Christian doctrine will be more comprehensive if it focuses on a specific region or ethnic group; however, in this country doctrinal differences are more manifest along denominational than regional or ethnic lines. Unlike the mission-oriented denominations, most of the African Initiated Churches do not prohibit divorce and remarriage; hence the target population of this article is the mainline groups most of which officially prohibit divorce and remarriage. ${ }^{1}$ Therefore, using the analytical and exegetical methods, the essay

* Submitted: 12/10/2018; peer-reviewed: 08/04/2019; accepted: 02/05/2019. Solomon O. Ademiluka, "“For I Hate Divorce," says the Lord: Interpreting Malachi 2:16 in Relation to Prohibition of Divorce in Some Churches in Nigeria," Old Testament Essays 32 no. 3 (2019): 846 - 868. DOI: https://doi.org/10.17159/2312- 
examines the intent of Mal 2:16 in relation to the prohibition of divorce by these churches and some Nigerian preachers. The article employs the analytical approach in studying the citation of Malachi 2:16 as a prohibition of divorce by these churches and preachers; while it exploits the exegetical method for the study of Mal 2:10-16 with a view to ascertaining the intent of verse 16 . To achieve its aim, the article first examines the use of Mal 2:16 in the prohibition of divorce by some Nigerian churches and preachers; it then does a brief introduction to the book of Malachi. Next, it discusses the figurative and literal interpretations of Mal 2:10-16, and subsequently Mal 2:16 as it relates to divorce. Finally, the article brings out the relevance of Mal 2:16 in the Nigerian context.

\section{B MALACHI 2:16 AND PROHIBITION OF DIVORCE IN NIGERIA}

In the traditional African society, the generally accepted norm was that marriage was indissoluble. One significant factor that assisted this concept was the fact that marriage was not an affair between two individuals but an alliance between two families. Family involvement was very conspicuous right from declaration of intention to the wedding ceremony. This practice often acted as a social support and security for marriage in that whenever a crisis threatened the survival of the marriage, the family would intervene and save it. ${ }^{2}$ As a result of this, divorce was very rare. ${ }^{3}$ A major factor that could warrant divorce was barrenness of a wife. ${ }^{4}$ This was because unlike in western society where marriage was person-oriented, "that is, the concept of marriage as companionship," in the traditional African setting marriage was fertility-oriented. ${ }^{5}$ In Mbiti's explanation, in Africa, "The supreme purpose of marriage is to bear children to build a family, to extend life and to hand down the living torch of existence ... [hence] if there is not yet a child in the marriage people do not consider it to be

3621/2019/v32n3a5.

The categorisation is, however, not that strict because some of the new AICs prohibit divorce while some of them do not.

2 Takim A. Ojua, Felicia E. Lukpata and ChimezieAtama, "Exploring the Neglect of African Family Value Systems and its Effects on Sustainable Development," American Journal of Human Ecology 3/3 (2014), 43-44.

3 Joachim Oforchukwu, "A Biblical and Theological Study (Analysis) of Marriage and Divorce among Igbo Catholic Christians (Nigeria)," M. A. Thesis, South African Theological Seminary, 2010, 45.

4 Even barrenness of a wife might not necessarily lead to divorce of the wife; in most cases the result was polygamy (John S. Mbiti, African religions and philosophy [Heineman: London, 1969], 133).

5 Mary R. Emenusiobi, "Africa: A Continent of Love for Life and Children," Evangelsus-life Africa, online,http://maryrosanna4life.blogspot.com/; cf. Alexander I. Abasili, "Seeing Tamar through the Prism of African Woman: A Contextual Reading of Genesis 38", Old Testament Essays24/3 (2011), 567. 
a marriage [and] there is no guarantee that the marriage will endure." ${ }^{\prime 6}$ In the past, it was as if a barren woman deliberately refused to "give her husband children, [so] she was considered to have failed him - and society - in the most serious way possible. And if he chose to consider his marriage null and void and send her back to her family, society - and the woman herself - would agree."7

However, Christianity came with a different notion of marriage. In the Christian perspective marriage is not instituted solely for procreation but also for companionship. Therefore, "marriage persists as a whole manner and communion of life and maintains its value and indissolubility, even when despite the often intense desire of the couple offspring is lacking." 8 The church views Christian marriage as a covenant more than a contract as husband and wife become one flesh and only death can break this bond; this means that Christian marriage can be dissolved only by death. ${ }^{9}$ In Nigeria the first generation of churches, namely, the mission-oriented denominations, inherited this concept of marriage in which divorce is forbidden for whatever reason. Some of the later generations, the African Initiated Churches, departed from this doctrine as their members do practise polygamy, divorce and remarriage. ${ }^{10}$ However, this article focuses on those denominations and preachers who proclaim an outright prohibition of divorce, relying on biblical passages, particularly Malachi 2:16.

The commonest context for the declaration that divorce is forbidden is the solemnization of marriage, the occasion during which couples are admonished to adhere to the Christian tenets on marriage.' "One of these tenets is the dogma of 'for better for worse,' which means the couple must accept the consequences of their decision whatever the outcome, good or bad;"11 that is, divorce is not allowed. As earlier mentioned, most of the mainline denominations officially adhere to this teaching, in which couples are expected to "endure whatever

6 John S. Mbiti, Mbiti, African religions and philosophy (London: Heineman, 1969), 132-133;

cf. Hephzibah Egede, "The Social Stigmatisation of Involuntary Childless Women in Sub-Saharan Africa: The Gender Empowerment and Justice Case for Cheaper Access to Assisted Reproductive Technologies?" PhD Thesis, Cardiff University, Wales, 2015, 65; Elijah E. Baloyi, "Gendered Character of Barrenness in an African Context: An African Pastoral Study," In Die Skriflig 51/1 (2017), a2172. https://doi.org/ 10.4102/ids. 20v51i1.2172.

7 "Marriage and the Family in Africa" unlabelled, online, http://www.cormacburke .or.ke/node/288.

8 Oforchukwu, "A Biblical and Theological Study (Analysis) of Marriage and Divorce," 57.

9 Oforchukwu, "A Biblical and Theological Study (Analysis) of Marriage and Divorce," 63.

10 Samuel W. Kunhiyop, African Christian Ethics (Nairobi: WordAlive), 250.

11 Usha Anenga, "Role of the Church in Marriage," The Guardian 26 November 2017, https://guardian.ng/opinion/role-of-the-church-in-marriage/. 
challenge they are facing ... even at the risk of their lives."12 For example, the Constitution of the Diocesan Synod of the Diocese of Lagos West (Anglican Communion) emphasises that "The Church believes that marriage, by divine institution is a life-long and exclusive union and partnership between one man and one woman. Indeed the Church's rites at marriage ceremonies state as much. It is a union that endures till 'death do us part."'13 Perhaps, the definiteness of the prohibition of divorce can be illustrated with the position of the Roman Catholic Church. In obedience to Jesus' teaching,

... the Church believes that marriage is a lifelong bond (cf. Mt 19:110)...The Catholic Church does not permit divorce for valid sacramental marriages. In fact a valid sacramental marriage is impossible to dissolve thereby making divorce not possible if the marriage was sacramental. In marriage the two become one flesh in a union joined by God (Mk 10:8-9). ... So for a marriage that meets the requirements of being a sacrament, divorce in the Catholic Church is not possible. ${ }^{14}$

Oforchukwu, however, mentions that the Catholic Church may cause physical separation of a couple for various causes such as "adultery or lapse into infidelity or heresy on the part of husband or wife" 15 but the marriage remains intact.

Nevertheless, the Catholic Church practices what it calls marriage annulment which can easily be confused with divorce, even though the denomination maintains that the two are different from each other. Whereas divorce is a civil law decree from the state, an annulment occurs when,

... a Church tribunal declares that a marriage thought to be valid ... actually fell short of ... the essential elements required for a binding union... [Hence] an annulment basically says that the Sacrament of Matrimony never took place to begin with... [Thus whereas] a civil divorce basically says that what was once a marriage is no longer

12 "Divorce Law and Practices among Christians," Refworld Nigeria, http://www.ref world.org/docid/50aa3f7a2.html.

13 BamboAdesanya, "Marriage, Divorce and Succession: The Legal Aspects, paper presented at a seminar marking the tenth anniversary of the Diocese of Lagos West on 12 June 2009," online, https://tinyurl.com/y7yxd34v.

14 Tessy Moore, "Why it's Hard to get a Divorce in Catholic Church," City People Magazine May 11 2017, online, http://www.citypeopleonline.com/hard-get-divorcecatholic-church/.

$\frac{15}{15}$ Oforchukwu, "A Biblical and Theological Study (Analysis) of Marriage and Divorce," 62. 
amarriage... a Church annulment declares that the Sacrament of Matrimony didn't occur from day one. ${ }^{16}$

Frequently, preachers in Nigeria condemn divorce relying on the Malachi passage. Pastor Adeboye of the Redeemed Christian Church of God, basing his sermon on Malachi 2:13-16, once declared that "divorce represents a kind of bereavement because out of it comes severe damage and destruction of important personal relationships. God hates divorce ...." 17 According to Oni, "No matter what view one takes on the issue of divorce, it is important to remember Malachi 2:16: "I hate divorce, says the LORD God of Israel." "18 In the same vein, Fayemiwo, citing Mal 2:16, declares that "the Holy Bible says emphatically that the True Lord God Almighty is against divorce." ${ }^{19}$ Also preaching on divorce, Dada wonders why "we take pleasure in doing what God hates and think it will not have consequences .... God says 'I hate divorce' -Malachi 2:16." ${ }^{20}$ Another preacher accuses Christians who divorce their wives of being guilty of what Prophet Malachi condemned in his book. The Jews in the day of Malachi "whimsically got rid of their faithful wives, just to make room for [new ones]... It's what prompted Prophet Malachi to write: one should not be disloyal to the wife he took in his youth. 'I hate divorce,' says the Lord God of Israel."21

Thus, relying on Mal 2:16 many preachers quote God as saying he hates divorce. Later on the article compares several English translations of the text with the Masoretic Text (MT) with a view to determining which is the most probable translation. Now, the work considers a brief introduction to the book of Malachi.

\section{A BRIEF INTRODUCTION TO THE BOOK OF MALACHI}

The book of Malachi opens with "The oracle of the word of the Lord to Israel by Malachi" (1:1, RSV). Unlike in the other prophetic books, this superscription gives no information concerning the prophet's ancestry or place of birth; neither

16 Moore, "Why it's Hard to get a Divorce in Catholic Church," http://www.city peopleonline.com/hard-get-divorce-catholic-church/.

17 "Pastor Adeboye's Advice on Marriage: God Hates Divorce," NaijaGist.com, https://naijagists.com/pastor-adeboyes-advice-on-marriage-god-hates-divorce.

18 Olamide Oni, "10 Things the Bible says about Divorce," Pulse.ng, https://www. pulse.ng/communities/religion/marriage-10-things-the-bible-says-about-divorce-id442 1823.

19 MoshoodFayemiwo, "Born-again Christians and their Worldly Views on Marriage," Nigeriaworld, https://nigeriaworld.com/feature/publication/fayemiwo/103117.

20 Amos Dada, "Don’t Divorce Your Spouse." Nigeriaworld, https://nigeriaworld. com/feature/publication/amos-dada/061817.

21 "Can a Christian Divorce and Remarry?" Nairaland Forum,https://www.naira land.com/3120389/christian-divorce-remarry. 
is he called a prophet. ${ }^{22}$ In view of the terseness of the introduction and the fact that the Hebrew מלאכי (Malachi) literally means 'my messenger,' some scholars contend that 'Malachi' is not a proper name but a pen name. The prophecy originally circulated as an addition to the book of Zechariah. ${ }^{23}$ But there are others who hold that there was a prophetic individual named Malachi. ${ }^{24}$ Redditt opines that the book of Malachi in its present form is a redaction from two previously existing collections authored by a non-Zadokite Levite at the Jerusalem temple. ${ }^{25}$ However, scholars seem to be in agreement in fixing the date of Malachi to the post-exilic era (or the Persian period). Matthews, for example, places the book between 500 and 450 B. C. E. because it "reflects the activities of the priestly community immediately after the reconstruction of the Jerusalem temple" in $515 .{ }^{26}$

In studying the theological purpose of Malachi scholars have identified six so-called disputations couched in a somehow unique format. In a disputation the prophet gives a charge to the accused, followed by "a hypothetical audience response, and an answer that leaves the accused with no further recourse." 27 A good example is found 2:17:

You have wearied the LORD with your words. Yet you say, "How have we wearied him?" By saying, "Everyone who does evil is good in the sight of the LORD, and he delights in them."

At the heart of these disputations stands the covenant, three of which are mentioned explicitly, namely, "the covenant with Levi (2:8), the covenant of the fathers, and the covenant of marriage (2:10-16)." ${ }^{28}$ Hence, in the six disputations Hugenberger recognises Malachi's wake-up call to his fellow-Israelites, in their cynicism and religious malaise, "to renewed covenant fidelity." 29 In the first of the disputations $(1: 2-5)$ the prophet defends the reality of God's elective love for Israel, which calls for their covenantal obedience and sincere worship. In the second one (1:6-2:9) Malachi identifies the ways in which the priests were dishonouring God, for which he castigates them. In the opinion of Hugenberger

22 TremlerLongman III \& Raymond B. Dillard, An Introduction to the Old Testament (Grand Rapids, Michigan: Zondervan, 2006), 497).

23 Christian J. Gertz, Angelika Berlejung, Konrad Schmid, \& Markus Witte, T\&T Clark Handbook of the Old Testament (London: T\&T Clark Int'1, 2012), 521.

24 Gordon P. Hugenberger, "Malachi" in New Bible Commentary, ed.Donald. A. Carson, Gordon J. Wenham, J. Alec Motyer, and Richard T. France (Nottingham: IVP, 1994), 883; cf.Longman \& Dillard, An Introduction to the Old Testament, 498.

25 Paul Redditt, "The Book of Malachi in its Social Setting," The Catholic Biblical Quarterly 56/2 (1994), 241.

26 Matthews, The Hebrew prophets and their social world: an introduction, 194.

27 Boloje, "Malachi's use of תורה," 254.

28 Longman \& Dillard, Introduction to the OT, 500.

29 Hugenberger, "Malachi," in New Bible Commentary, 884. 
in $2: 10-16$, the third disputation, the message concentrates on interfaith marriage between the Israelites and foreign women as unfaithfulness to Israel's covenant with Yahweh, as well as divorce as infidelity against covenanted marriages between husbands and wives. ${ }^{30}$ In the fourth of the disputations (2:17-3:5), the prophecy turns eschatological as the author foretells future vindication for the righteous which will take place when the messenger of the covenant comes to judge the wicked. In 3:6-12, which is the fifth disputation, Malachi returns to the issue of the people sacrificing poor offerings to the Lord, for which reason they had experienced material adversity. In 3:13-4:3, the sixth disputation, the author assures the Israelites who thought that evildoers had escaped divine justice due to their prosperity, that they will yet be judged, while Yahweh will vindicate those who fear him. Chapter 4:4-6 seems to be a summary of the prophecy in which the audience is enjoined to "remember the law of Moses and the promise of Elijah and the coming day of the Lord." ${ }^{31}$ To ascertain the most probable translation and interpretation of Mal 2:16, in the following section the article undergoes an exegesis of 2:10-16.

\section{MALACHI 2:10-16: THE FIGURATIVE VERSUS LITERAL INTERPRETATION}

Although there seems to be two ideas treated in Mal 2:10-16, one in 10-12, the other in 13-16, both are connected by the opening phrase of verse 13, וזאת שנית תעשו ("and this second [thing] you do"). Thus, the two sections "condemn two parallel, though not necessarily related, marital offenses." 32 The first offense is described as Israel's unfaithfulness to one another, which profanes their covenant with Yahweh who is Israel's Father and Creator (v. 10). It also apparently involves mixed marriages with people of foreign religions (11-12). The second section (13-16) is generally attested to be problematic. In verse 13 the men of Judah were distressed because God would not accept their offerings and was withholding blessings from them, which verse 14 puts down to "their broken marriage vows" 33 to the wives of their youth and covenant, marriage to which God was a witness. Verse 15 is rather obscure but seems to emphasise the understanding of marriage as a covenant, ${ }^{34}$ and warns against "treacherous dealings against one's wife." ${ }^{35}$ Verse 16 is also problematic but it is clear that it condemns divorce, apparently as violence against the divorced.

30 As shown presently, some give this portion a figurative interpretation as against the literal expressed here.

31 Hugenberger, "Malachi," in New Bible Commentary, 884.

32 Hugenberger, "Malachi," in New Bible Commentary, 886.

33 Carl J. Laney, "No Divorce and no Remarriage," in Divorce and Remarriage: Four

Christian Views, ed. Wayne H. House (Illinois: Intervarsity Press, 1990), 29.

34 Hugenberger, "Malachi," in New Bible Commentary, 887.

35 Laney, "No Divorce and no Remarriage,"30. 
There are two main approaches to the interpretation of Mal 2:10-16, namely the figurative and literal interpretations. The figurative approach postulates that the passage refers not to literal marriage but marriage as a metaphor for Israel's relationship with Yahweh. ${ }^{36} \mathrm{O}$ 'Brien takes this position, making reference to prophetic passages (such as Hos 2:7; Jer 2:2; 3:7-11; 3:20; $31: 32$; Ezk 16:60) that commonly compare the relationship between Yahweh and Israel to that of husband and wife. According to her,

Within these passages Yahweh is always analogous to the male, and the female figure is Israel, Judah or Jerusalem. The people's failure to worship Yahweh exclusively is compared to adultery, which in turn is a matter of shame for the male and deserving of punishment for the female. In terms of recurrent vocabulary, Yahweh is said to have 'married' the land; infidelity is called 'treachery;' and 'youth' often is considered the time of happiness and fidelity... [Hence] Malachi utilizes this prophetic discourse of idolatry as adultery. ${ }^{37}$

Similarly, Matthews asserts that Mal 2:10-16 "is actually a metaphorical reference to the marriage between Israel and Yahweh under the covenant," 38 even though he recognises that in this, unlike other prophetic texts, Israel is the husband while the wife is Yahweh. Matthews believes that if the Malachi passage is interpreted as a reference to human marriages, it would contradict the demands made by Ezra and Nehemiah (Ez 9:1-10:5; Neh 13:23-31) ${ }^{39}$ that mixed marriages must be dissolved or annulled. ${ }^{40}$ Some scholars are in favour of a בַת בתאל נכר (the daughter of a foreign god) in verse 11 must refer to a goddess. It is observed that the expression is "totally uncommon and ambiguous," 41 and that if it was meant to designate foreign women, as some who hold the literal view claim, the phrase would have been expressed as נשים נכריות (e.g., as in $1 \mathrm{Kgs} \mathrm{11:1,} \mathrm{8;} \mathrm{Ez}$ 10:2; Neh 13:26) since an ordinary woman is never called a daughter of a god. ${ }^{42}$ To buttress this view, it is also observed that the language of verses 10-12 is strikingly "saturated with cultic associations." 43

36 Hugenberger, "Malachi," New Bible Commentary, 887.

37 Julia M. O'Brien, "Judah as Wife and Husband: Deconstructing Gender in Malachi," Journal of Biblical Literature 115/2 (1996), 246.

38 Matthews, The Hebrew prophets, 196.

39 It is commonly agreed that Malachi shares the same socio-historical context with Ezra-Nehemiah, and addresses similar social issues.

40 Matthews, The Hebrew prophets, 196.

41 Markus Zehnder, "A Fresh Look at Malachi 2:13-16," Journal of Biblical Literature 53/2 (2003), 229.

42 Beth Glazier-McDonald, "Intermarriage, Divorce, and the Bat-'el Nekar: Insights into Mal 2:10-16," Journal of Biblical Literature 106/4 (1987), 604.

43 Zehnder, "A Fresh Look at Malachi 2:13-16,” 228. 
However, a figurative interpretation based on the views expressed above needs to be re-examined. In the first place, the view that Yahweh is wife in metaphorical marriage relationship is foreign to the well-known prophetic traditions. As Hugenberger rightly notes, "everywhere else in scripture where the marriage metaphor appears God is uniformly depicted as the husband, not the wife, as would be the case here." ${ }^{44}$ For this reason, a figurative interpretation of Mal 2:10-16 would contradict this normal "order in which Israel is the bride and Yahweh the groom." 45

Furthermore, it may not be correct that בּת־אל נכר can only refer to a goddess. As Glazier-McDonald observes, such a view would imply that 'the children of Yahweh' (Deut 14:1; 32:19; Hos 11:1; Isa 1:2) would be gods, whereas the term indisputably applies to the people of Israel. In the same vein, the Moabites are called sons and daughters of Chemosh in Num 21:29 and they are not gods but worshipers of the Moabite god. ${ }^{46}$ More importantly, both בַת נשים נכריות in verse 11. A linguistic link is observable between

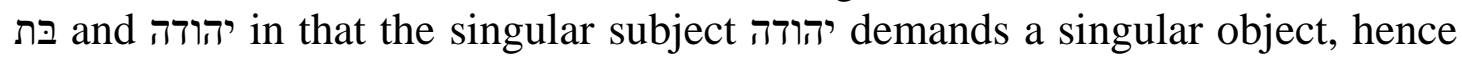
"the concept of Judahite men as children of Yahweh (v.10a) is best matched by the designation of the foreign women as 'daughter of another god." "47 The preference of בפת־־ over נשים נכריות is also explicable from the religious perspective as marriage with women of foreign religious background had implications in "the religious domain due to their non-Jahwistic affiliation." 48 As expressed by Glazier-McDonald, the sentence בַת־ אל נכרבּעל "graphically demonstrates the consequences of intermarriage. Marriage to a foreign woman meant that her god and cult were allied with that of Yahweh and, as a result, his paternity, his creative effort as אל Israel's behalf is obscured, even rejected or usurped."49 Glazier-McDonald asserts that the expression נשים נכריות cannot adequately evoke all these associations. This explanation may in turn account for the phenomenon of a language strikingly associated with cultic expressions earlier observed.

If בּת־אל נכר designates foreign women, a literal interpretation of condemnation of divorce in Mal 2:16 does not contradict the demand for dissolution of mixed marriages in Ezra-Nehemiah, as some have suggested. In both Ezra-Nehemiah and Malachi Jewish men are accused of association with foreign women which indicates that the two contexts deal with the same problem

\footnotetext{
44 Hugenberger, "Malachi," in New Bible Commentary, 887.

45 Zehnder, "A Fresh Look at Malachi 2:13-16," 228.

46 Glazier-McDonald, "Intermarriage, Divorce, and the Bat-'el Nekar," 604.

47 Zehnder, "A Fresh Look at Malachi 2:13-16," 228; cf. Glazier-McDonald, "Intermarriage, Divorce," 604.

48 Zehnder, "A Fresh Look," 228.

49 Glazier-McDonald, "Intermarriage, Divorce," 604.
} 
of association with foreign nations as a violation of the law of Yahweh that Israel should dissociate herself from the heathen nations. ${ }^{50}$ The lands of these nations were unclean, "Therefore give not your daughters to their sons, neither take their daughters for your sons ..." (Ez 9:12; Neh 13:25; cf. Exod 34:16; Deut 7:3). The issue of divorce in both contexts is also related to this Mosaic Law. In EzraNehemiah the demand for divorce is because of marriage with foreign women while in Malachi divorce is condemned because it is done in order to marry foreign women. Therefore, rather than being in contradiction, Mal 2:16 is perfectly in harmony with the demand for dissolution of mixed marriages in Ezra-Nehemiah. Nonetheless, Glazier-McDonald believes that both the figurative and literal interpretations are not mutually exclusive. In her view,

[While] the literal interpretation that views these verses as a condemnation of intermarriage and divorce gives a not undue prominence to the social aspect of these actions, the figurative or syncretistic interpretation brings the religious consequences to the forefront ... Taken alone, however, each of these interpretations is incomplete... Thus, any attempt to penetrate to the ipsissima verba of this oracle unit must take both into account. ${ }^{51}$

On the contrary, there are compelling factors that commend the literal interpretation over the figurative. Starting with the responses to the figurative approach, we have seen that the view of a metaphorical marriage in which Israel/Judah is husband and Yahweh is wife runs contrary to the normal pattern in the prophetic traditions. In that case בּעל בּּת־א נכר in Mal 2:11 is properly interpreted to refer to marriage with women of foreign religious affiliations. In this way, the literal interpretation of Mal 2:10-16 is supported by the demand for dissolution of foreign marriages in Ezra-Nehemiah. Furthermore, there are linguistic terms that are suggestive of real human relationships such as exist between husband and wife. This can be seen, for instance, in the expressions which are used in verse 14 to identify the women, viz. אשיר נעוריך (the wife of אשרת בּריתך (your wife by covenant), and particularly the term אברך (Aouth) (your companion). Also crucial is "the remark about Yahweh being witness of the relationship between these women and their husbands," also in verse $14 .{ }^{52}$ This would not make much sense in a metaphorical marriage between Yahweh and Judah since the concept of witness to a marriage covenant must necessarily involve three parties; a marriage partner cannot be the witness in his/her own marriage. In verse 14, therefore, Yahweh is the third party, the witness between the husband and his wife. Hence Zehnder is right when he affirms that,

50 As noted earlier, it is hardly disputed that both of Malachi and Ezra-Nehemiah have the same historical context of the Persian period and address similar social problems.

51 Glazier-McDonald, "Intermarriage, Divorce," 611.

52 Zehnder, “A Fresh Look,” 229. 
... in Mal 2:13-16 the linguistic net that refers to real relations between a husband and his wife turns out to be very tight; by the same token, any clear hint that the verses should not be understood literally is missing. [These] factors indicate that verses 13-16 actually deal with conjugal relations between men belonging to the Yahwehcongregation and their wives. ... This observation, in turn, makes it probable that the preceding 10-12 is not to be understood exclusively in the figurative sense, but rather has in mind marriages between members of the Yahweh-congregation and women of foreign faiths. ${ }^{53}$

The suggested link between verses $10-12$ and 13-16 is also observable from the linguistic perspective, which would in turn support the literal interpretation. This has to do with the term בגד that occurs five times in the passage and has been translated as meaning 'faithless' or 'treacherous.' In verse 10 the prophet queries why the men of Judah were faithless to one another, and in the following verse gives his reason for this accusation, namely that they had married women of foreign faiths. In verse 14 the prophet identifies the wives of their youth as the ones "to whom you have been faithless," while in 15 he admonishes every Judahite man against being "faithless to the wife of his youth." It is significant to note that verse 16 opens with the conjunction כי כhich has severally been translated as 'for' thereby linking the verse with the preceding one. Thus, in verse 16 the prophet explains בגד in pragmatic terms as שלה , the putting away of wives. This suggestion that by 'treachery' the author of Malachi 2:10-16 most likely had divorce in mind is buttressed by the fact that the verse ends with the admonition, "So take heed to yourselves and do not be faithless" (RSV). The two segments, Mal 2:10-12 and 13-16 is therefore harmonized by the word בגד, and this harmony suggests that in Mal 2:10-16 the author had in mind two basic issues, namely mixed marriages and divorce. As we shall see below, the proposition that Mal 2:10-16 focuses on mixed marriages and divorce would in turn support the view that Jewish men were divorcing their Jewish wives in order to marry foreign women. In conclusion Zehnder's summary is apposite:

[W] hile in [Mal 2:10-12, the relationship of members of the Yahwehcongregation with women of foreign faiths is denounced, 13-16 deals with the faithlessness of the same addressees towards those women that belong to the Yahweh-congregation as they themselves do. Even if the text does not explicitly say so, one has to assume that the two aspects are interrelated: the addressed men break faith with their first, Israelite, wives because they marry women of foreign faiths. ${ }^{54}$

The conclusion that the Malachi passage is reference to human marriage and divorce has been supported by interpreters in various ways. Longman and

53 Zehnder, "A fresh Look," 228.

54 Zehnder, “A Fresh Look,” 230. 
Dillard simply state that "the Israelites were apparently divorcing their nativeborn wives in order to take up foreign wives who worshiped idols." 55 Drane attributes this act of the Jewish men to the fact they wanted "more attractive younger women," "56 the view that is similar to that of Richards that the "men were deserting the "wives of their youth'... to marry younger women." ${ }^{57}$ According to Snyman, other interpreters have suggested other possible reasons for the behaviour of these men. Perhaps, "they wanted more security; or that the first wife held a place of honour and the new foreign wives would not tolerate a subordinate position in the household; or that there were all kinds of economic reasons for trading one's wife for a foreign woman." 58 However, as Zehnder appropriately notes, no other possible reasons for the divorces are adduced in the text apart from the relationship with women of foreign faiths. And for this reason, divorce became "an even greater ethical problem than had divorce been sought for another reason." 59 This scenario would further support the view of affinity with the problem of mixed marriages in Ezra-Nehemiah. However, there is an additional aspect in Malachi which is lacking in Ezra-Nehemiah, namely that relationships with foreign women "were contracted at the expense of previously existing marriages with Israelite wives," who were now not only being slighted in this way but even being sent away. ${ }^{60}$

Thus far this essay has argued in favour of the literal view that Mal 2:1016 treats the issues of mixed marriages and divorce. In the following section the article investigates the most probable intent of Mal 2:16 in relation to divorce.

\section{E MALACHI 2:16 IN RELATION TO DIVORCE}

Mal 2:16 is one of the most difficult texts in the HB, so much that it has "engaged significant scholarly debate" 61 at least since the beginning of the twentieth century, being "the source for many discussions and suggested emendations." 62 This fact is reflected glaringly in the multiple, sometimes contradictory English

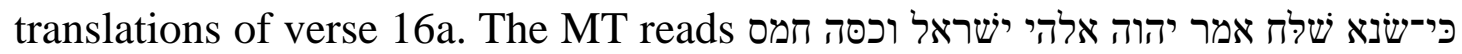
על־לבושו אמר יהוה צבאות. As it is, the text is in the perfect but, perhaps being an oracle it is usually translated in the present, in which case it would literally read, "For he hates sending away, says Yahweh the God of Israel, and he covers

55 Longman \& Dillard, Introduction, 501.

56 John Drane, Introduction to the Bible $2^{\text {nd }}$ ed. (Minneapolis: Fortress, 2012), 170.

57 Larry Richards, "Divorce and Remarriage under a Variety of Circumstances," in Divorce and remarriage: Four Christian views, ed. Wayne House (Illinois: Intervarsity Press, 1990), 218.

58 Snyman, "A Theological Appraisal,” 605.

59 Zehnder, "A Fresh Look" 230.

60 Zehnder, "A Fresh Look," 231.

61 O’Brien, "Judah as Wife and Husband," 245.

62 Russell Fuller, "Text-Critical Problems in Mal 2:10-16," Journal of Biblical Literature 110/1 (1991), 50. 
violence upon his garment, says Yahweh of hosts."63 The most conspicuous problem is the confusion created by the unlikely expression "For he hates sending away, says Yahweh the God of Israel;" hence as shown below some have noted correctly that the clause אמר יהוה אלהי ישראל must have been inserted later. Another problem is the question of the subject of the two main verbs, שנא (to hate) and כסה (to cover), both being in the third person. If Yahweh is the one who hates, is he the one who also "covers violence upon his garment"? Out of the twelve English versions ${ }^{64}$ consulted, nine make Yahweh the subject of שנא and out of these nine, eight put verse 16a in the direct speech: "I hate divorce...." These eight may have all converted to direct speech the KJV's indirect, "For the LORD, the God of Israel, saith that he hateth putting away..." This may then explain the popular proclamation in sermons, as seen earlier, that God hates divorce. However, the ESV makes "the man," not God, the subject of both שנא and כסה, rendering the passage as, "For the man who hates and divorces ... covers his garment with violence." This is similar to the NIV's "The man who hates and divorces his wife ... does violence to the one he should protect." A few translations seem to make the hating and putting away conditional, making שלח (sending away) contingent upon שנא. For example, the DRA has "When thou shalt hate her put her away ... but iniquity shalt cover his garment." Similarly, the GNV renders the verse as, "If thou hatest her, put her away ... yet he covereth injury under his garment ...." These last two seem to compound the problem as one part is in second person singular (thou) whereas the other is put in third person masculine singular (his/he), so that the reader does not know the relationship between "who hates" and "who covers violence upon his garment." The ESV of 2001 and NIV of 2011 are relatively recent publications, and this makes their departure from other translations very significant in that it indicates that the age-long question of the correct translation and meaning of Mal 2:16 may not have been resolved after all; for as demonstrated below there is evidence of efforts being made since the ancient times to resolve this problem. In other words, that Mal 2:16 is problematic is shown not only in the attempts at its translation but also in the history of its interpretation.

As regards the history of the interpretation of the text, there are witnesses from Qumran, the LXX, and the Targum Jonathan ${ }^{65}$ which indicate that efforts

63 שלח "to send away," is generally found in the piel to mean "to divorce" a wife (Hermann J. Austel "שלח" in TWOT 2:928).

64 The American Standard Version (ASV); the Douay-Rheims American Edition (DRA); the English Standard Version (ESV); the Geneva Bible (GNV); the New Jewish Publication Society (JPS); the King James Version (KJV); the New American Bible (NAB); the New International Version (NIV); the New Jerusalem Bible (NJB); the New Living Translation (NLT); and the Revised Standard Version (RSV); the World English Bible (WEB).

65 Targum Jonathan on the prophets is one of those targa (or targums), Jewish Aramaic translations and explanations of books of the Hebrew Bible. 
were probably made to reinterpret the MT. For instance, this is seen in 4QXII ${ }^{\mathrm{a}}$, a manuscript of the Minor Prophets from Cave 4 at Qumran, dated 150-125 B. C. E. that contains fragments from Mal 2:10 to the end of the book. ${ }^{66}$ According to Fuller, in 4QXII a verse 16 opens with כי אם, which means "but if" in this context, and corresponds exactly to the reading of Targum Jonathan. Thus, in 4QXII ${ }^{\mathrm{a}}$ and the Targum the opening of the MT seems to have been understood as marking the beginning of a conditional clause. ${ }^{67}$ This might be so if attempt was being made to reconcile Mal 2:16 with Deut 24:1-4 which allows divorce for sexual immorality. This suggestion of possible effort at reconciliation is supported by Fuller who states that in $4 \mathrm{QXII}{ }^{\mathrm{a}}$ is read as the masculine singular imperative of the Piel, as against the infinitive construct of the MT, the effect of which would be to allow for divorce. Fuller opines that,

If this understanding is adopted, then the reading of 4 QXII ${ }^{\mathrm{a}}$ may be translated ... "if you hate (her) send (her) away!" [And] this translation of the text is in complete agreement with the text of the targum, the Vulgate, and it is close to one of the oldest Greek witnesses. ${ }^{68}$

Perhaps, it was the readings of these witnesses that informed the conditional translations of the DRA and GNV noted above. However, Jones objects to the assumption that the LXX has a condition and an imperative in the second person, maintaining that rather, it has a participle and a subjunctive. In that case, it does not say "If you hate divorce" but "If hating you divorce" (i.e., if you divorce out of hatred), with apodosis still to come as in the Hebrew. ${ }^{69}$

כי־שנא שליה In view of the grammatical difficulty presented by the opening of the MT, some have suggested a repointing of this phrase. H. Ewald, ${ }^{70}$ for example, repointed the perfect שנא to participle and the infinitive construct שלח as infinitive absolute. Van Hoonacker ${ }^{71}$ improved on this and repointed the infinitive as a perfect to match וכסה in the apodosis. Adopting Van Hoonacker's repointing, Glazier-McDonald translated Mal 2:16a as "For one who divorces because of aversion... thereby covers his garment with violence ...."72 According to Jones, this is the reading supported by the LXX since the sixteenth century C. E. but, unfortunately, due to the assumption mentioned above that the

66 Fuller, "Text-Critical Problems," 47.

67 Fuller, "Text-Critical Problems," 55.

68 Fuller, "Text-Critical Problems," 55.

69 David C. Jones, "A Note on the LXX of Malachi 2:16," Journal of Biblical Literature 109/4 (1980), 684.

70 Cited in Jones, "A Note on the LXX," 683.

71 Cited in Jones, "A Note on the LXX," 683.

72 Cited in Jones, "A Note on the LXX," 683. 
LXX has a condition and an imperative, this "reading of the consonantal text has so far escaped notice." 73

Thus, as earlier mentioned, the interpretive difficulty of Mal 2:16 lies in the correlation between the two clauses, כי־שנא של של (For he hates sending away) and וכסה חמס על־לבושו (and he covers violence upon his garment). Since both clauses are in the third person singular, as Zehnder plausibly suggests they should have the same subject. The traditional translation "For I hate divorce ..." loses sight of this fact and introduces "a change of subject between the two halves of verse 16a [which] seems to be unnecessary and cumbersome." $" 74$ As earlier noted, the same problem is manifest in the translations of the DRA and GNV that put the first clause in the second person singular and the other in the third person. The most probable reconstruction would then have to start with making the two clauses to have the same subject, while recognising that the first clause is a protasis and the second one its apodosis..$^{75}$ To achieve this, שנא is interpreted as Qal participle (i.e., 'hates' in this context), and שלח as Piel third person masculine singular perfect but read in the present simple (i.e., 'sends away'). ${ }^{76}$ Following this reconstruction the sentence would read "For [he] who hates and divorces covers his garment with violence."77 This suggestion agrees with GlazierMcDonald's recommendation: "For one who divorces because of aversion ... thereby covers his garment with violence ...."78 Jones is also of the view that "this makes excellent sense in the context, and the translations of NEB and the New Vulgate Edition, among others, reflect the same reading of the text." 79 As earlier seen, this translation is also close to those of the ESV and the NIV. One factor that commends this interpretation over the traditional translation "For I hate divorce..." as rightly emphasised by Hugenberger, is that "it understands the subject of 'hate' as the divorcing husband, rather than God." ${ }^{80}$ Moreover, this interpretation is more probable than the traditional one as the latter's apparent blanket condemnation of divorce would contradict the more lenient view of divorce in Deut 24:1-4. ${ }^{81}$ As Zehnder puts it, "the interpretation of outright rejection of divorce by Yahweh would be astonishing" not only in view of Deut 24:1-4 but also of the attitude to divorce in Ezra 10. ${ }^{82}$ In respect to Deut 24:1-4, there are indications that the text prominently influenced Jewish custom on divorce in later Judaism. This is reflected, for example, in Mt 19:3-12 where

\footnotetext{
73 Jones, "A Note on the LXX," 684.

74 Zehnder, "A Fresh Look," 253.

75 Zehnder, "A Fresh Look," 254.

76 Zehnder, A Fresh Look," 254.

77 Zehnder, A Fresh Look," 255.

78 Cited in Jones, "A Note on the LXX," 683.

79 Jones, "A Note on the LXX," 683.

80 Hugenberger, "Malachi," in New Bible Commentary, 887.

81 Hugenberger, "Malachi," in New Bible Commentary, 887.

82 Zehnder, “A Fresh Look," 256.
} 
Jesus apparently makes reference to Deut $24: 1-4 .{ }^{83}$ Another reason why the rendering of Mal 2:16a favoured here is plausible is that it makes redundant the clause אמר יהוה אלהי ישראל which in the MT renders the verse "unnecessarily cumbersome." ${ }^{\prime 4}$ Zehnder affirms that this clause is considered to be secondary. According to him, apart from the fact that the phrase makes the verse unnecessarily difficult, it also does not appear elsewhere in Malachi, unlike the אמר יהוה צבאות which is found copiously in the book. The reason for the insertion is not clear, but it is conceivable that it was meant to strengthen the clause "כי־שנא שלח "as an exhortation to divorce or as a general prohibition of divorce." $" 85$

It is pertinent to point out that the interpretation of Mal 2:16 being suggested here, particularly in Glazier-McDonald's view, "For one who divorces because of aversion ... thereby covers his garment with violence ..." is in agreement with the conclusion that Mal 2:10-16 addresses the situation in which Jewish men were divorcing their native Jewish wives in order to marry women of foreign faiths. In that case the protasis כיישנא של describes how these Jewish men behaved: "they 'hate' their Israelite wives because they appear to them as inferior ... hence they expel" them. ${ }^{86}$ Various suggestions have been made for the interpretation of the apodosis וכסה חמס על־לבושו. Some have suggested that it is possible לבוש is used here metonymically to refer to the marriage covenant; the suggestion that is plausible in the context of Jewish marriage ceremonies, part of which was the spreading of garment over a woman to claim her as wife (cf. Ezk 16:8; Ruth 3:9; Deut 22:30). ${ }^{87}$ However, in this passage לבוש is better understood "as a figurative expression of the person himself and his inner character;" וכסה חמס על־לבושו may in "be understood to refer to the stain which the sin of divorce leaves, like the blood of a victim on the garment of the murderer." 89 This proposition may be buttressed by Zech 3:4 where a soiled cloth indicates uncleanness of heart. ${ }^{90}$ In this way, if the protasis

83 Jesus' contemporary Jewish society must have understood the law as permitting divorce. The Pharisees ask Jesus the question on divorce "in order to test him," i.e., possibly to know which of the contemporary views he supported. In Jesus' day there were the schools of Shamai that argued that Deut 24:1-4 allowed divorce due to adultery, and of Hillel who taught that the text permitted a man to divorce his wife for any reason (Craig S. Keener, The IVP Bible Background Commentary: New Testament [Illinois: IVP, 1993], 96; Jay E. Adams, Marriage, Divorce and Remarriage in the Bible [Philipsburg: Presbyterian \& Reformed, 1980], 51).

84 Zehnder, "A Fresh Look," 257.

85 Zehnder, "A Fresh Look," 257.

86 Zehnder, "A Fresh Look,"255.

87 Zehnder, “A Fresh Look,” 256; Laney, "No Divorce and no Remarriage," 31.

88 Zehnder, "A Fresh Look," 256.

89 Laney, "No Divorce and no Remarriage," 31.

90 Laney, "No Divorce and no Remarriage," 31. 
describes the behaviour of the Jewish men who divorced their wives out of hate to marry foreign women, then the apodosis וכסה חמס על־לבושו further depicts divorce as "a severe wrong" from Yahweh's own evaluation. ${ }^{91}$ In other words, although divorce is not illegal, "the expulsion of their wives in order to marry another woman of foreign faith is a moral wrong in the eyes of Yahweh."92According to Zehnder, the phrase וכסה חמס על־לבושו is a figurative description of all kinds of wrongdoing but here it is applied specifically to the men's act of divorcing their native wives in order to marry foreign women. ${ }^{93} \mathrm{He}$ who divorces for this reason covers his garment with violence, that is, "visibly defiles himself with violence." 94 This interpretation is further supported by texts where violence covering a person as garment refers metaphorically to character. For example, in Ps 73:6 the phrase "violence covers them as a garment" refers to the conduct of the wicked" ${ }^{95}$ (cf. Ps 109:18; Jer 2:34).

Thus, the popular translation of Mal 2:16 as "For I hate divorce, says the Lord..." misses the intent of the text. The translations such as those of the ESV and NIV which make the man who divorces, rather than God, the subject of the verse are the more probable translations. In this way, the text does not intend to say that God hates divorce; neither does it purport to prohibit divorce generally. Rather, it castigates certain Jewish men who hated and divorced their old native wives in order to marry women of foreign faiths. For the prophet, divorce for this reason amounts to treachery for two reasons. Firstly, the divorced wives were innocent since there is no hint that they were guilty of sexual immorality which could be reason for divorce according to Deut $24: 1-4 .{ }^{96}$ Secondly, the purpose of divorce was to marry women of non-Jahwistic tradition, which is against Mosaic Law, as earlier discussed. In other words, if the women were guilty of immorality, and the new wives were of the Yahweh-congregation, the men had no offense. In view of this, Mal 2:16 does not forbid divorce generally. As Edgar puts it, the text "cannot be automatically applied to all cases of divorce." 97 Therefore, in the contemporary times Mal 2:16 is relevant not as a prohibition of divorce, but in the context of wife abandonment especially for the purpose of

\footnotetext{
91 Zehnder, “A Fresh Look," 256.

92 Zehnder, "A Fresh Look," 256.

93 Zehnder, "A Fresh Look," 256.

94 Hugenberger, "Malachi," in New Bible Commentary, 887.

95 Alec J. Motyer, "Psalms," in New Bible Commentary, ed. Donald. A. Carson, Gordon J. Wenham, J. Alec Motyer, and Richard T. France (Nottingham: IVP, 1994), 532.

96 Hugenberger, "Malachi," in New Bible Commentary, 887.

97 Thomas R. Edgar, "Divorce and Remarriage for Adultery or Desertion," in Divorce and Remarriage: Four Christian Views, ed. Wayne House (Illinois: Intervarsity Press, 1990), 153; cf. Richards, "Divorce and Remarriage," 218.
} 
pursuing other women. It is in this perspective that the text is applied to the Nigerian context in the section below.

\section{F RELEVANCE OF MALACHI 2:16 IN THE NIGERIAN CONTEXT}

Abandonment or desertion of wife is a frequently occurring form of domestic violence towards women today. ${ }^{98}$ It takes several forms but generally it involves "men going away from home and leaving the children and mother without any support." 99 A recent form of this violence is the so-called "transnational marriage abandonment" "100 that is said to be common in the UK. According to Patel and Anitha, there are three main forms of this abuse, namely:

a) a woman migrates to the UK after marriage and is abused and abandoned or is forced to flee within this country;

b) a woman is brought to the UK and then deceived into returning to her home country on some pretext and abandoned there, while her husband returns to the UK, revokes her visa and initiates divorce proceedings;

c) a woman is married or left behind in her home country following her marriage, usually with her in-laws, and is never sponsored to come to the UK. ${ }^{101}$

Anitha et al. report the prevalence of this type of "abandonment of wives by Indian-origin men domiciled in another country" particularly the UK. ${ }^{102}$ However, marriage abandonment is not suffered by only Indian women; it is rampant also in Nigeria.

Due to the prevalence of abandonment of marriage in Nigeria the Nigerian Family Laws list it as one of the factors for which application for divorce can be

98 Kunhiyop, African Christian Ethics, 244.

99 ObyNwakwo, "Effectiveness of Legislation Enacted to Address Violence against Women in Nigeria," paper presented at Expert Group Meeting on Good Practices in Legislation on Violence against Women, United Nations Office, Vienna, Austria 26 to 28 May 2008, 4, online: https://tinyurl.com/ybqoxkzo; cf. Udo Osisiogu, "Physical Abuse of Women in the Home: A Nigerian Perspective," Humanities and Social Sciences Review 05/3 (2016), 380.

100 Pragna Patel \& SundariAnitha, "Transnational Marriage Abandonment: A New Form of Violence against Women?" OpenDemocracy,https://tinyurl.com/yca5wow8.

101 Patel \&Anitha, "Transnational Marriage Abandonment," https://tinyurl.com/yca5 wow8; cf. SundariAnitha, Harshita Yalamarty\& Anupama Roy, "Changing Nature and Emerging Patterns of Domestic Violence in Global Contexts: Dowry Abuse and the Transnational Abandonment of Wives in India," Women's Studies International Forum (2018), 8-9.

102 Anitha et al., "Changing Nature and Emerging Patterns of Domestic Violence," 3. 
granted in court. ${ }^{103}$ Wife desertion takes different forms. In a reported case, "the husband forced his wife out of the matrimonial home, and abandoned her for three years without any maintenance." 104 Desertion may occur in the form of a husband isolating his wife completely even when they still live together in the same house. In such a case the husband "cooks his own food, sleeps in a separate room, denies his wife sex and fails to communicate with her." 105 Another form of marriage abandonment happens when a man deliberately moves out of the matrimonial home without the consent of his wife, leaving her and the family to their own fate. There are cases where a "husband travels out of the country, in search of greener pastures, and never comes back to his wife(family) or gets married to (or cohabitates permanently) with another woman. ... This is the present reality of lots of married people in Nigeria." ${ }^{106}$ Another type of wife desertion in Nigeria has to do with men entering into extra-marital love affairs. They begin to come home late or spending some nights out of the matrimonial home. In such a home the wife and the children become destitute if the husband is the sole bread winner of the family. This behaviour is reminiscent of that of the so-called 'sugar daddies' who are well known in Nigeria. The term is used to describe elderly men who enter into illicit love affairs with young girls of the age of their own children, thereby abandoning their wives and families. ${ }^{107}$ Wife abandonment may, therefore, not necessarily involve official divorce, but the women who are thus maltreated fare little better than being divorced. Sometimes an abandoned wife may not even know the whereabouts of her husband for months, sometimes for years. Apart from the resulting insecurity in the home, the woman may also be saddled with the responsibility of looking for her husband. In some instances, instead of her in-laws being there to sympathise with the deserted woman, they threaten to do her the worst harm if their relative is not found. They may even blame her for the man's disappearance, sometimes accusing the woman of possibly using her husband for rituals. To this end, a deserted wife may face a lot of psychological suffering. Mal 2:16 condemns this act as treachery and violence against women whether it involves divorce or not. However, it is pertinent to note that sometimes a man's extra-marital affair is caused by his wife's misdemeanour. Some men may use this form of abuse as a

103 Andreas Rahmatian, "Termination of Marriage in Nigerian Family Laws: the Need for Reform and the Relevance of the Tanzanian Experience," International Journal of Law, Policy and the Family 10, (1996), 286.

104 Hightower Lawyers, "When a Spouse Abandons Marriage after the Wedding," Legalnaija, online, https://www.legalnaija.com/2017/02/desertion-when-spouseabandons-marriage.html.

105 Hightower Lawyers, "When a Spouse Abandons Marriage after the Wedding," https://www.legalnaija.com/2017/02/desertion-when-spouse-abandons-marriage.html. 106 Hightower Lawyers, "When a Spouse Abandons Marriage after the Wedding," https://www.legalnaija.com/2017/02/desertion-when-spouse-abandons-marriage.html. 107 Lola Delano, "Sexual Abuse and Violence in Sub-Saharan Africa," Advocates for Youth, online, https://tinyurl.com/q5her32. 
response to women "who nag, disobey or want to take over the seat of authority from the man, who is always revered as the head of the house." 108 Other attitudes of a woman that can push a man into extra-marital affair include denial of conjugal rights, laziness in performing her house duties, among others. ${ }^{109}$ These traits may induce the husband to begin to avoid his home, seeking peace elsewhere.

It is important to note, however, that although Mal 2:16 focuses specifically on Jewish men who abandoned their native wives for non-native women, in Nigeria the message of the prophet is applicable also to women who are treacherous towards their husbands. It is common knowledge in Nigeria that, like their male counterparts, some married women similarly indulge in extramarital affairs. In some cases such women eventually leave their husbands for other men, sometimes leaving their children behind. This type of scenario is illustrated in the case between James Nnanna and his wife, Jane. The Customary Court in Aba-la-Ohazu in Abia State dissolved their marriage on account of Jane's wilful desertion of her matrimonial home for several years. ${ }^{110}$ In cases such as this, the same economic and psychological effects that a deserted woman suffers are applicable to an abandoned husband. Therefore, the message of Malachi is applicable also to women who are treacherous in this way.

\section{G CONCLUSION}

In some English translations of Mal 2:16 God is reported as saying he hates divorce. Hence, for some churches and preachers in Nigeria the text is the handiest biblical passage in support of prohibition of divorce. This attitude, however, ignores a few other English versions that make the man who divorces, rather than God, the subject of hating and divorcing. The research found that Mal $2: 16$ castigates certain Jewish men in the post-exilic community who divorced their native wives in order to marry women of foreign faiths. It was also discovered that in view of other OT texts, particularly Deut 24:1-4 that favours divorce, Mal 2:16 could not have prohibited it as implied in some English versions. Rather, what the text condemns is treachery on the part of these men in terms of abandoning their wives for other women. Mal 2:16 is therefore relevant in contemporary Nigeria, not as a prohibition of divorce, but in the context of wife abandonment, which is a form of women abuse today not only in Nigeria but in many parts of the world. In this regard the passage speaks to men who desert their wives and families to pursue other women. The prophet says this is

\footnotetext{
108 Monica Agene, "The Reality of Domestic Violence in Nigeria," Women for Women International, online, https://tinyurl.com/yc4g5gfv.

109 Joseph Enuwosa, "Africentric Hermeneutics: Divorce Option in Matthew 5:32 in Urhobo Cultural Context," African Journal of Biblical Studies XXIII/I (2005), 60.

110 Hightower Lawyers, "When a Spouse Abandons Marriage after the Wedding," https://www.legalnaija.com/2017/02/desertion-when-spouse-abandons-marriage.html.
} 
treachery, whether or not the act involves divorce. Implicitly, it is also treachery on the part of women who similarly abandon their husbands and families for other men.

\section{BIBLIOGRAPHY}

Abasili, Alexander I., 2011. "Seeing Tamar through the Prism of African Woman: A Contextual Reading of Genesis 38." Old Testament Essays 24/3 (2011): 555-573.

Adams, Jay E. Marriage, Divorce and Remarriage in the Bible. Philipsburg: Presbyterian \& Reformed, 1980.

Adesanya, Bambo. "Marriage, Divorce and Succession: The Legal Aspects. Paper presented at a seminar marking the tenth anniversary of the Diocese of Lagos West on 12 June 2009," https://tinyurl.com/y7yxd34v.

Agene, Monica. "The Reality of Domestic Violence in Nigeria." Women for Women International, https://tinyurl.com/yc4g5gfv.

Anenga, Usha. "Role of the Church in Marriage." The Guardian 26 November 2017. https://guardian.ng/opinion/role-of-the-church-in-marriage/.

Anitha, Sundari, Harshita Yalamarty and Anupama Roy. "Changing Nature and Emerging Patterns of Domestic Violence in Global Contexts: Dowry Abuse and the Transnational Abandonment of Wives in India." Women's Studies International Forum (2018):1-33. https://doi.org/10.1016/j.wsif.2018.05.005.

Anon. "Pastor Adeboye's Advice on Marriage: God Hates Divorce." NaijaGist.com, https://naijagists.com/pastor-adeboyes-advice-on-marriage-god-hates-divorce/.

Anon. "Can a Christian Divorce and Remarry?" Nairaland Forum,https://www.naira land.com/3120389/christian-divorce-remarry.

Anon. "Divorce Law and Practices among Christians." Refworld Nigeria, http://www. refworld.org/docid/50aa3f7a2.html.

Baloyi, M. Elijah. "Gendered Character of Barrenness in an African Context: An African Pastoral Study." In Die Skriflig 51/1, a2172. https://doi.org/10.4102/ ids.v51i1.2172.

Boloje, Blessing O. "Malachi's use of תורה in Dialogue with the Wisdom Tradition of Proverbs." Old Testament Essays 31/1 (2018): 243-263. https://doi.org/10. 17159/2312-3621/2018/v31n1a12.

Dada, Amos. "Don't Divorce Your Spouse." Nigeriaworld, https://nigeriaworld.com /feature/publication/amos-dada/061817.html.

Delano, Lola. "Sexual Abuse and Violence in Sub-Saharan Africa." Advocates for Youth, https://tinyurl.com/q5her32.

Drane, John. Introduction to the Bible $2^{\text {nd }}$ ed. Minneapolis: Fortress, 2012.

Edgar, Thomas R. "Divorce and Remarriage for Adultery or Desertion." Pages 151-196 in Divorce and Remarriage: Four Christian Views. Edited by Wayne H. House. Illinois: Intervarsity Press, 1990.

Egede, Hephzibah. "The Social Stigmatisation of Involuntary Childless Women in SubSaharan Africa: The Gender Empowerment and Justice Case for Cheaper Access to Assisted Reproductive Technologies?" PhD Thesis, Cardiff University, Wales.

Emenusiobi, Mary R. "Africa: A Continent of Love for Life and Children." Evangelsuslife Africa, http://maryrosanna4life.blogspot.com/.

Enuwosa, Joseph. "Africentric Hermeneutics: Divorce Option in Matthew 5:32 in Urhobo Cultural Context.” African Journal of Biblical Studies XXIII/I (2005): 49-72. 
Ewald, G.H.A. Commentary of the Prophets of the OT. Translated by J. F. Smith. London: Williams, 1881.

Fayemiwo, Moshood, "Born-again Christians and their Worldly Views on Marriage." Nigeriaworld, https://nigeriaworld.com/feature/publication/fayemiwo/103117.html.

Fuller, Russell. "Text-Critical Problems in Mal 2:10-16." Journal of Biblical Literature 110/1 (1991): 47-57.

Gertz, J. Christian, Angelika Berlejung, Konrad Schmid, \& Markus Witte. T\&T Clark Handbook of the Old Testament. London: T\&T Clark Int'1, 2012.

Glazier-McDonald, Beth. "Intermarriage, Divorce, and the Bat-'el Nekar: Insights into Mal 2:10-16." Journal of Biblical Literature 106/4 (1987): 603-611. https://doi. org/10.2307/3260822.

Harris, R. Laird, Gleason L. Archer, Jr., and Bruce K. Waltke, eds. Theological Wordbook of the Old Testament. 2 vols. Chicago: Moody Publisher, 1980.

Hightower Lawyers. "When a Spouse Abandons Marriage after the Wedding." Legalnaija, https://www.legalnaija.com/2017/02/desertion-when-spouse-abando ns-marriage.html

Hugenberger, Gordon P. "Malachi." Pages 883-889 in New Bible Commentary. Edited by Donald. A. Carson, Gordon J. Wenham, J. Alec Motyer, and Richard T. France. Nottingham: IVP, 1994.

Jones, C. David. "A Note on the LXX of Malachi 2:16." Journal of Biblical Literature 109/4 (1980): 683-685.

Keener, Craig S. The IVP Bible Background Commentary: New Testament. Illinois: IVP, 1993.

Kunhiyop, Samuel W. African Christian Ethics. Nairobi: Word Alive, 2008.

Laney, Carl J. "No Divorce and no Remarriage." Pages 15-54 in Divorce and Remarriage: Four Christian Views. Edited by Wayne H. House. Illinois: Intervarsity Press, 1990.

Leadership Editor. "Court Dissolves Marriage over Wife Desertion of Matrimonial Home." Leadership Newspaper 15 May 2017. Online: https://leadership.ng/ 2017/05/15/court-dissolves-marriage-wife-desertion-matrimonial-home/.

Longman, Tremper III \& Raymond B. Dillard. An Introduction to the Old Testament. Grand Rapids, Michigan: Zondervan, 2006.

"Marriage and the Family in Africa." Unlabelled, http://www.cormacburke.or.ke/ node $/ 288$.

Matthews, Victor H. The Hebrew Prophets and Their Social World: An Introduction. Grand Rapids: Baker Academic, 2012.

Mbiti, John S. African Religions and Philosophy. London: Heineman, 1969.

Moore, Tessy. "Why it's Hard to get a Divorce in Catholic Church." City People Magazine May 11, 2017. Online: http://www.citypeopleonline.com/hard-getdivorce-catholic-church/.

Motyer, Alec J. "Psalms.” Pages 485-583 in New Bible Commentary. Edited by Donald. A. Carson, Gordon J. Wenham, J. Alec Motyer, and Richard T. France. Nottingham: IVP, 1994.

Nwakwo, Oby. "Effectiveness of Legislation Enacted to Address Violence against Women in Nigeria." Paper presented at expert group meeting on good practices in legislation on violence against women, United Nations Office, Vienna, Austria 26 to 28 May 2008. Pages 1-49. Online: https://tinyurl.com/ybqoxkzo. 
O’Brien, Julia M. "Judah as Wife and Husband: Deconstructing Gender in Malachi." Journal of Biblical Literature 115/2 (1996): 241-250. https://doi.org/10.2307/ 3266854.

Oforchukwu, I. Joachim, “A Biblical and Theological Study (Analysis) of Marriage and Divorce among Igbo Catholic Christians (Nigeria). M. A. Thesis, South African Theological Seminary, 2010.

Ojua, T. Asu, Lukpata, F. Ekwok \&Atama, Chimezie. "Exploring the Neglect of African Family Value Systems and its Effects on Sustainable Development." American Journal of Human Ecology 3/3 (2014): 43-50. https://doi.org/10.1163 4/216796221504585.

Oni, Olamide, "10 Things the Bible says about Divorce." Pulse.ng, https://www. pulse.ng/communities/religion/marriage-10-things-the-bible-says-about-divorce -id4421823.html.

Osisiogu, Udo. "Physical Abuse of Women in the Home: A Nigerian Perspective." Humanities and Social Sciences Review 05/3 (2016):379-394.

Patel, Pragna\&Sundari Anitha. "Transnational Marriage Abandonment: A New Form of Violence against Women?" OpenDemocracy, https://tinyurl.com/yca5wow8.

Rahmatian, Andreas. "Termination of Marriage in Nigerian Family Laws: the Need for Reform and the Relevance of the Tanzanian Experience." International Journal of Law, Policy and the Family 10 (1996),281-316. https://doi.org/10. 1093/law fam/10.3.281.

Richards, Larry. "Divorce and Remarriage under a Variety of Circumstances." Pages 215-248 in Divorce and remarriage: Four Christian views. Edited by Wayne H. House. Illinois: Intervarsity Press, 1990.

Redditt, Paul L. "The Book of Malachi in its Social Setting." The Catholic Biblical Quarterly 56/2 (1994): 240-255.

Snyman, Fanie. "A Theological Appraisal of the Book of Malachi." Old Testament Essays 27/2 (2014): 597-611.

Van Hoonacker, A. Les Douze Petits Prophetes: traduits et Commentes. Paris: Gabalda, 1908.

Zehnder, Markus. “A Fresh Look at Malachi 2:13-16." Journal of Biblical Literature 53/2 (2003): 224-259.

Solomon Olusola Ademiluka, Department of Biblical and Ancient Studies, University of South Africa; Department of Religious Studies, Kogi State University, Anyigba, Nigeria; solademiluka@gmail.com; +2347036127452; All private correspondence to P. O. Box, 379, Anyigba, Kogi State, Nigeria. ORCID: https://orcid.org/0000-0001-9390-2510. 